\title{
Production of Ethylene and Other Volatiles and Changes in Cellulase and Laccase Activities during the Life Cycle of the Cultivated Mushroom, Agaricus bisporus
}

\author{
By ELIZABETH M. TURNER \\ White Queen Ltd., Yaxley, Peterborough PE7 3 EG \\ M. WRIGHT, T. WARD AND DAPHNE J. OSBORNE \\ Agricultural Research Council, Unit of Developmental Botany, \\ Cambridge $C B_{3}$ oDY \\ AND R. SELF \\ Agricultural Research Council, Food Research Institute Norwich NR4 7 UA
}

(Received 28 April I975)

SUMMARY

Nine volatile hydrocarbons, as well as methyl chloride, carbonyl sulphide and carbon disulphide, have been identified by mass spectrometry as products of Agaricus bisporus in the compost used in commercial mushroom beds. Of these, only ethylene showed a pattern of production that could be correlated with developmental phases of the crop, high levels being produced whenever fruit bodies were rapidly enlarging.

In laboratory flask cultures, under controlled conditions, high levels of ethylene occurred whenever young fruit bodies entered the expansion phase. The enhanced rate of ethylene production continued over several days, irrespective of whether fruit bodies were removed. Production occurred within the colonized compost; no ethylene was evolved by the fruit body itself.

When the first fruit bodies expanded, either in beds or culture flasks, laccase levels in the compost fell and those of a $\beta$-I,4-glucanase (cellulase) rose. The enzyme switch occurred once only, during maturation of the first fruit bodies, whereas an elevated ethylene production was associated with each occasion when fruit body maturation took place.

The low level of laccase and high level of cellulase characterized the whole of the reproductive stage of $A$. bisporus, whereas the phasic periods of high ethylene production distinguished between periods of fruit body maturation and intervening resting periods.

\section{INTRODUCTION}

Agaricus bisporus (Lange) Sing., the cultivated mushroom, has two phases in its life history: a vegetative mycelial phase, followed by a reproductive, fruit body-forming phase. The change from one phase to the other occurs as a result of covering colonized compost with a layer of non-sterile peat or soil, mixed with lime, known as 'casing soil'. This results in the formation of fruit body initials which develop some days later into mature mushrooms. Despite numerous studies, the factors which control initiation and development are still not clearly defined. Eger (1972) showed that bacteria in the casing play an essential though unknown role in initiation. Mader (1943) and Sinden (quoted by Schisler, 1957) considered the involvement of volatile substances in the control of development, and the importance 
of $\mathrm{CO}_{2}$ has been clearly demonstrated : low concentrations enhance and high concentrations suppress initiation (Tschierpe \& Sinden, I964, I965; Long \& Jacobs, I974), and $\mathrm{CO}_{2}$ also enhances the subsequent elongation of the stipe (Lambert, I933).

Ethylene and a number of volatile substances including acetaldehyde, acetone, ethyl alcohol and ethyl acetate have been identified as products of $A$. bisporus during both the vegetative phase (Tschierpe \& Sinden, 1965; Richter, 1967) and reproductive phase (Lockard \& Kneebone, 1962), but their production has not, so far, been linked to a particular stage of development.

In higher plants, ethylene is a naturally produced growth regulator controlling many aspects of development (Abeles, 1973). A number of other unsaturated hydrocarbons (acetylene, propene) will also modify plant growth in a similar way, but at much higher concentrations.

With the view that similar controls may exist in fungi, we have examined the production of ethylene and other hydrocarbon volatiles during the life cycle of $A$. bisporus both in normal commercial beds and in the controlled conditions of laboratory cultures. We report the identification of these volatiles, and set out evidence from which we conclude that a high and phasic production of ethylene reflects specific stages in development. We also report major changes in the activity of the enzymes laccase and cellulase, which may reflect or determine the nature of the substrates utilized during the different phases of growth.

\section{METHODS}

Organism. Agaricus bisporus (White Queen strain No. I02) was used throughout.

Growth conditions. (i) Commercial beds. Following spawning and colonization of pasteurized compost by the vegetative mycelium, the compost was covered with a non-sterile 'casing soil' consisting of a mixture of peat and chalk. Initiation of fruit bodies took place after the mycelium had grown into the casing layer and was followed by development of mature mushrooms in a series of 'breaks'. Each break was picked over a period of 2 to 4 days with a 3 to 5-day resting phase during which the fruit bodies of the next break developed.

(ii) Laboratory culture. Samples ( $150 \mathrm{~g}$ ) of pasteurized compost (65 to $72 \%$ moisture content), similar to that of the commercial beds, were put into either $600 \mathrm{ml}$ or $\mathrm{I} 1$ conical flasks and autoclaved for $\mathrm{I} h$ at $20 \mathrm{lb} / \mathrm{in}^{2}$ on two successive days. To inoculate the compost, I2 grains of the spawn were scattered on the surface and the cultures incubated at $25^{\circ} \mathrm{C}$ for up to 23 days. Sterile or non-sterile casing ( $50 \mathrm{~g}, 75 \%$ moisture content) was then spread over the colonized compost and the flasks incubated at 20 or $25{ }^{\circ} \mathrm{C}$ for a further 4 to 18 days. They were then attached to air lines for continuous ventilation with humidified air at 16 or $20^{\circ} \mathrm{C}$. Many initials formed in the non-sterile casing and fruit bodies developed at intervals either singly or in pairs.

For measurements of volatiles, each flask was closed for up to $6 \mathrm{~h}$ with a rubber bung bored to accept a Suba-Seal (Freeman Ltd, Barnsley, Yorkshire). The accumulated volatiles were sampled at appropriate intervals for gas chromatographic analysis. Possible inhibition of fruiting by accumulation of $\mathrm{CO}_{2}$ was prevented by including a vial containing pellets of $\mathrm{KOH}$.

(iii) Laboratory culture for mass spectral analysis. Uncased cultures consisting of $250 \mathrm{~g}$ of compost in $\mathrm{I} 500 \mathrm{ml}$ conical flasks were incubated for I I to I4 days at room temperature. Immediately before sampling the flasks were autoclaved for Io min at $20 \mathrm{lb} / \mathrm{in}^{2}$.

Sampling procedures from commercial beds. For each crop, three representative trays were marked and samples of casing and compost were removed at intervals. Each sample 
was withdrawn with large flat-sided forceps to give a plug $(20 \mathrm{~g})$ of material which included a $25 \mathrm{~mm}$ depth of casing only, or compost only. The compost was removed from $20 \mathrm{~mm}$ below the compost surface of uncased trays or from just below the casing-compost interface of the cased trays. A $6 \mathrm{~g}$ portion from each plug was transferred to a boiling tube which was closed with a Suba-Seal and sampled $6 \mathrm{~h}$ later for determination of volatiles by gas chromatography. A second $6 \mathrm{~g}$ sample was assayed for laccase and cellulase activity. Dry weight values were obtained from a further $6 \mathrm{~g}$ sample.

Gas chromatographic assays of volatiles. Samples (I $\mathrm{ml}$ ) of the gas phase were withdrawn with a hypodermic syringe from the head space of either the sealed tubes containing samples from the mushroom beds, or the closed laboratory culture flasks. The gas sample was analysed by gas-solid chromatography in a Pye series 104 flame ionization gas chromatograph fitted with an $800 \times 4 \mathrm{~mm}$ glass column containing activated silica gel at $160{ }^{\circ} \mathrm{C}$ (column A) (for details see Jackson \& Osborne, 1972). Five peaks with retention times of less than $5 \mathrm{~min}$ were obtained and these were numbered $I$ to 5 in their order of elution from the column. They eluted with the retention times of ethane, ethylene, propane, propene and $n$-butane, respectively, as shown by co-chromatography with authentic standards. Values for ethylene are presented as $\mathrm{nl} / \mathrm{g}$ fresh weight/h and those for other volatiles are presented as rates of production in arbitrary units (based on peak height) for the periods of enclosure of both tubes and flasks.

Identification of volatiles by combined mass spectrometry and gas chromatography. The concentration of volatiles $I$ to 5 accumulating in the head space of a culture flask was found to be too low to permit direct analysis by mass spectrometry. Larger quantities of the same volatiles were obtained when the flasks were autoclaved for 10 min at $20 \mathrm{lb} / \mathrm{in}^{2}$ immediately before sampling: this procedure was therefore adopted for the identification of the gases.

Gas $(1500 \mathrm{ml})$ from above the autoclaved compost-mycelium was first passed through a $460 \times 4 \mathrm{~mm}$ pre-column packed with 40 to 60 mesh gelatin to remove water vapour, and then condensed in a concentric-tube trap at $-183^{\circ} \mathrm{C}$. The trap was connected into the carrier gas flow of the gas chromatograph (helium, $30 \mathrm{ml} / \mathrm{min}$ ) and the condensed volatiles (including copious amounts of $\mathrm{CO}_{2}$ ) were released by ohmic heating (10 $\mathrm{V}, 8 \mathrm{~A}$, d.c.) and simultaneous immersion of the body of the trap in water at $60^{\circ} \mathrm{C}$.

Preliminary experiments with column A showed that peaks 3, 4 and 5 contained more than one compound per peak. To obtain satisfactory mass spectra, a column with increased resolution but with similar properties to column A was prepared.

The Pye series 104 gas chromatograph was fitted with a $4 \mathrm{~mm}$ internal diameter glass column, $\mathrm{I} \cdot 52 \mathrm{~m}$ long, containing 80 to 100 mesh silicic acid at $180^{\circ} \mathrm{C}$ (column B). The emerging gas flow was divided in the ratio $2: \mathrm{I}$ between the silicone membrane separator inlet to the mass spectrometer and the flame ionization detector of the gas chromatograph. Mass spectra were obtained on an AEI MS902 mass spectrometer coupled to the gas chromatograph. The spectra were recorded in the mass range 12 to $100 \mathrm{~nm}$ using a ten second per decade scan speed and an ionization energy of $70 \mathrm{eV}$.

Twelve compounds were identified by comparing the unknown mass spectra with those of standard compounds listed by Cornu \& Massot (1966). The identities of ethane, ethylene, propane, propene and $n$-butane were further verified by co-chromatography with standard compounds. The gas chromatographic peak for propane included a trace quantity of carbonyl sulphide, and the peak for propene included a trace quantity of iso-butane. The remaining five compounds, all eluting later than $n$-butane, were methyl chloride, carbon disulphide, two unspecified isomers of butene, and $n$-pentane. For the purpose of this present study the five peaks detected on column A (Table I) were shown by co-chro- 


\section{Table I. Volatile compounds present in fully colonized compost or casing}

The compounds are listed in the order of their retention times as monitored by gas chromatography in column A.

$\begin{array}{lcc}\text { Compound } & \begin{array}{c}\text { Peak } \\ \text { assignation }\end{array} & \begin{array}{c}\text { Retention time } \\ \text { (s) }\end{array} \\ \text { Ethane } & \text { I } & 65 \\ \text { Ethylene } & 2 & 88 \\ \text { Propane } & 3 & 130 \\ \text { Propene } & 4 & 238 \\ n \text {-Butane } & 5 & 285\end{array}$

matography to contain the compounds assigned to them. Furthermore, the mass spectra which were taken over the whole region covered by the chromatogram show that peaks I and 2 were solely composed of ethane and ethylene respectively, and although peaks 3,4 and 5 contained some additional material, it is acceptable for the purpose of the quantitative analysis to refer to them as propane, propene and $n$-butane, respectively (Table I).

Enzyme estimations. Each compost sample was extracted in $30 \mathrm{ml}$ distilled water for $3 \mathrm{~h}$ at $17^{\circ} \mathrm{C}$. The resulting solution was then filtered through Whatman paper No. I and the filtrates were used directly for the determination of extracellular enzyme activities. Laccase assays were carried out at room temperature by a colorimetric method as described by Turner (1974) modified from Horowitz and Fling (1953). The sample to be assayed (0.25 ml) was added to $3 \mathrm{ml}$ of $0.1 \mathrm{M}-\mathrm{KH}_{2} \mathrm{PO}_{4}-\mathrm{Na}_{2} \mathrm{HPO}_{4}$ buffer, $\mathrm{pH} \mathrm{6.6}$, and $0.3 \mathrm{ml}$ of $0.2 \%(\mathrm{w} / \mathrm{v})$ aqueous solution of guaiacol (Koch-Light). Activity was measured using an Evans Electro Selenium Colorimeter fitted with filter No. 23, and was measured as an increase in extinction (colorimeter units) $/ \mathrm{mg}$ dry weight $/ 7 \mathrm{~min}$.

Cellulase ( $\beta$-I :4-glucanase) activity was determined according to a modified viscometric method described by Jackson \& Osborne (1972) using as substrate a I \% solution of high viscosity carboxymethylcellulose (BDH) in $0 \cdot 01$ M-phosphate buffer $\mathrm{pH} 6 \cdot 2$.

\section{RESULTS}

\section{Pattern of volatile production}

Preliminary determinations by gas chromatography (D. J. Osborne and M. B. Jackson, unpublished) indicated that five peaks representing low molecular weight volatiles are produced by samples of colonized compost or casing from mushroom beds. This work has been confirmed and the five peaks, including ethylene, have been identified by mass spectrometry. In addition, other volatile products, not previously reported from mushroom cultures, are now listed (see Methods).

The production of volatiles from compost and casing from commercial beds was monitored during the growth and development of several crops, and the statistical analysis of the values for the five peaks for one such crop, from the I 9 th to the 44th day after spawning, is presented in Table 2 . This shows that the production of all gases increased during colonization of the compost then declined from the 19th to the 33rd day after spawning, and that ethylene production was significantly higher than that of all the other gases at days 35, 40, 42 and 44. In Fig. I, the ethylene production from both compost and casing for this crop is plotted in relation to production of fruit bodies and it is seen that the days when high rates of ethylene production occurred are those on which many mature fruit bodies could be picked.

Measurements of the volatiles produced in the laboratory cultures by the compost and 


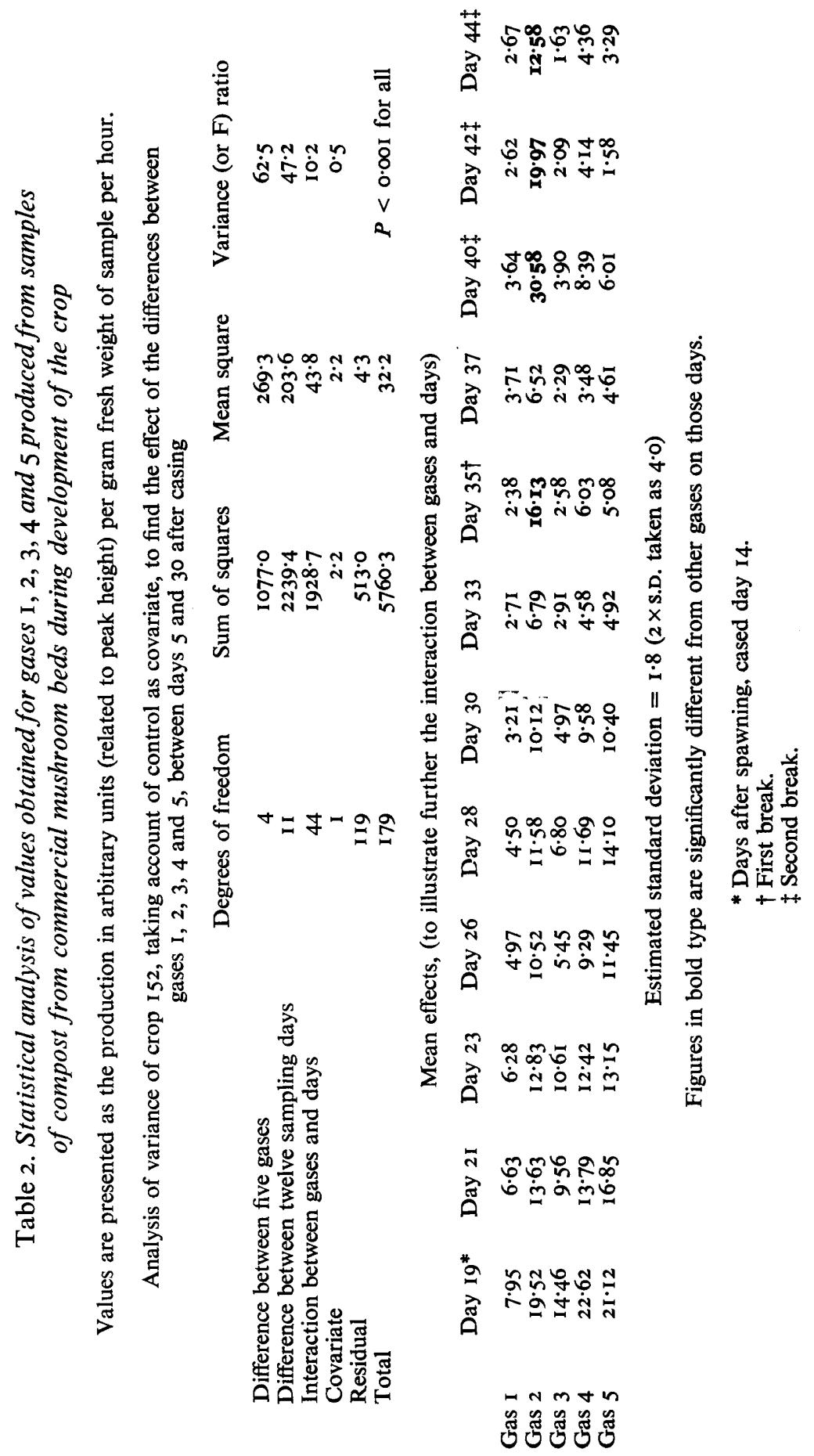




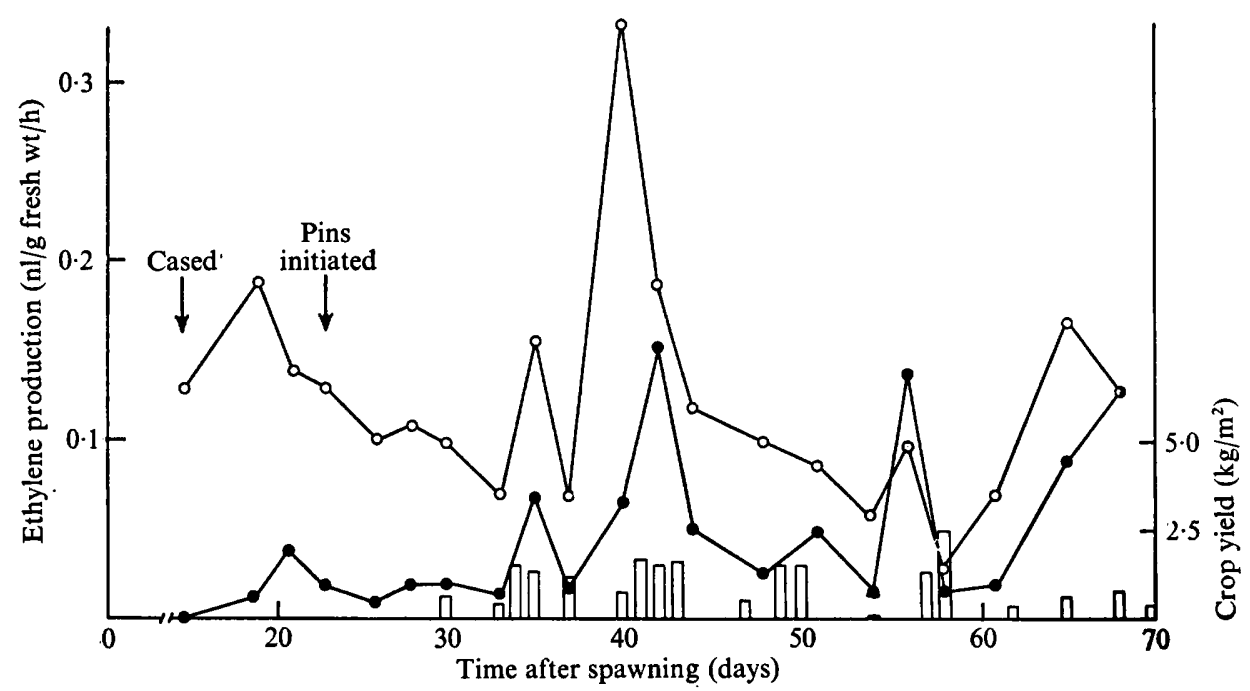

Fig. I. The yield (histogram) of mature fruit bodies from a commercial mushroom bed (crop 152 ) and the production of ethylene by samples of $(O)$ compost and $(\bullet)$ casing taken from the bed.

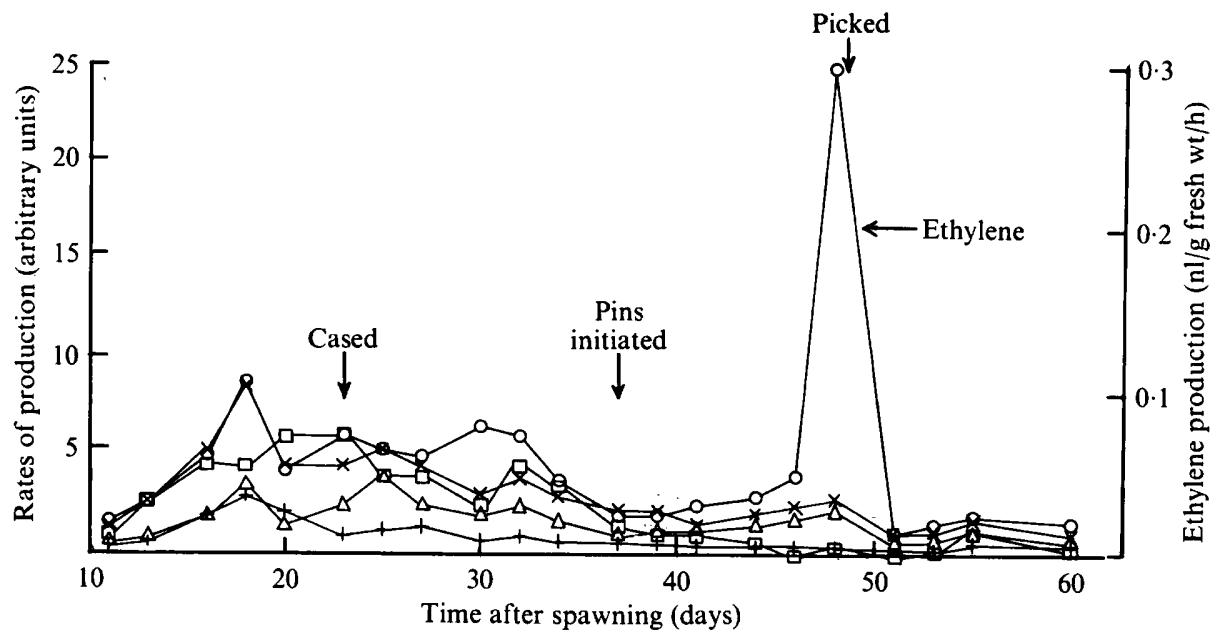

Fig. 2. Pattern of production of peaks $I$ to 5 during the development of a fruiting body in flask culture. $\square$, Peak I (ethane); $O$, peak 2 (ethylene); $\triangle$, peak 3 (propane); $\times$, peak 4 (propene); + , peak 5 (n-butane).

compost plus non-sterile casing indicated that their rates of production followed a pattern similar to that of the commercial beds (Fig. 2). The results again illustrate the general decline in the production of ethane, propane, propene and $n$-butane with time, and the steep rise that occurs in ethylene production when fruit bodies are developing. None of these gases was produced by sterile compost alone.

A more detailed analysis of the production of ethylene in relation to the stage of development of the fruit body is presented in Fig. 3. Although production rises during the early expansion of the fruit body it later declines, reaching a low level at autolysis or senescence of the fruit body. A similar pattern of production occurs if the fruit body is picked before 


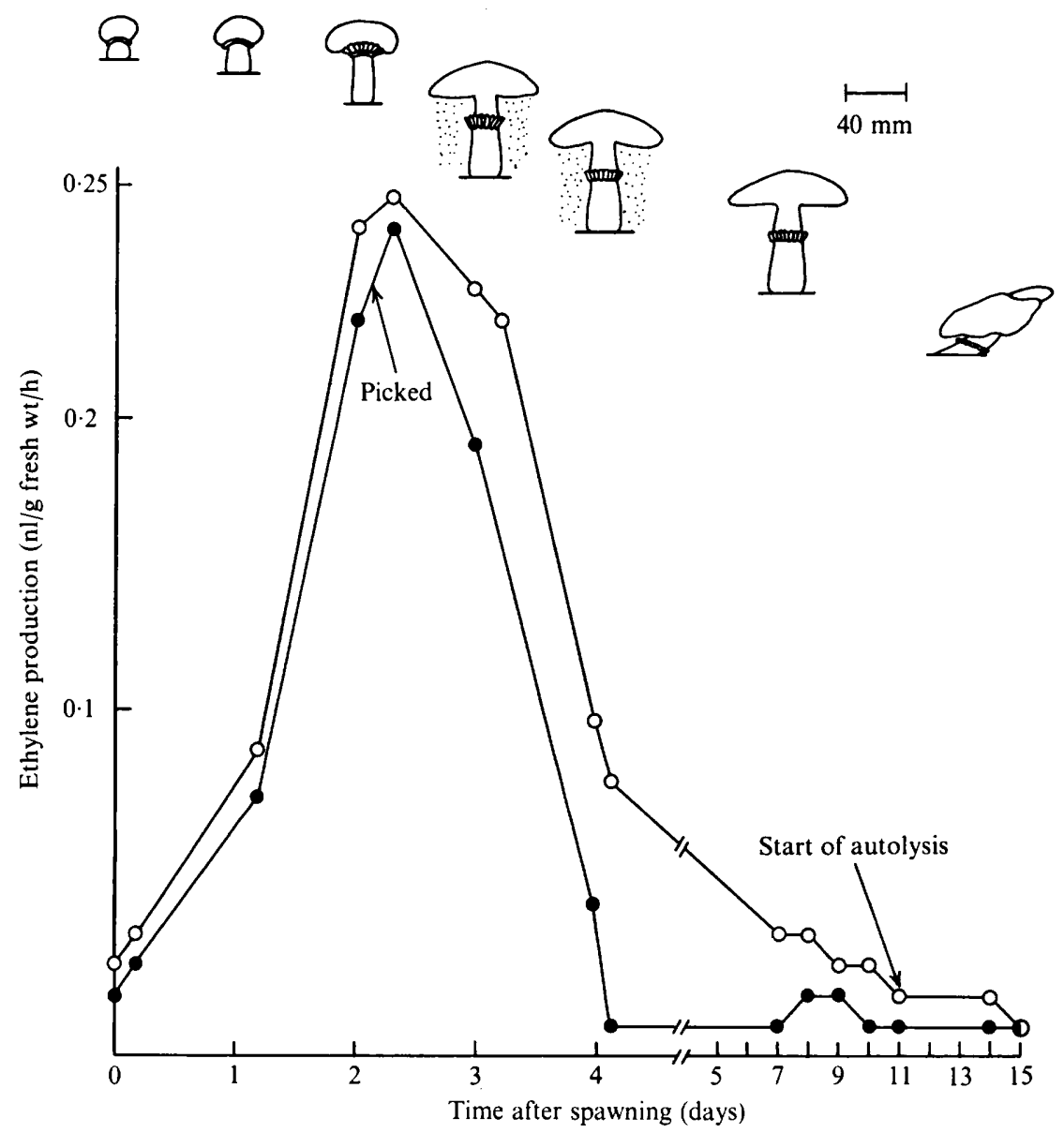

Fig. 3. Production of ethylene $(O)$ in flask culture during development and sensescence of a fruit body, and ( $)$ in a sister flask in which the fruit body was picked at the point indicated before full fruit body expansion. Flasks were cased i 4 days after spawning.

it is fully expanded. The high levels are therefore not attributable to the fruit body itself. Other data (not presented) have confirmed that fruit bodies do not themselves produce detectable levels of ethylene.

Picking is followed by the development of a second fruit body, again associated with a period of high ethylene evolution, and this has occurred up to four times in the same flask. Flasks which did not produce fruit bodies, either because of an adverse $\mathrm{CO}_{2}$ concentration or because the compost was cased with a sterile casing soil, did not show a peak of enhanced ethylene production.

\section{Enzyme activities during growth of the crop}

As previously reported (Turner, 1974), laccase activity in extracts of inoculated compost increased both during the period of colonization and after casing, but thereafter fell quite quickly to an undetectable level at the time when the first fruit bodies matured (Fig. 4). As the level of laccase activity fell, the level of cellulase activity rose, reaching, at fruiting, a high level which was then maintained throughout the subsequent cropping. Similar results were obtained from analysis of extracts of compost from the laboratory culture flasks. 


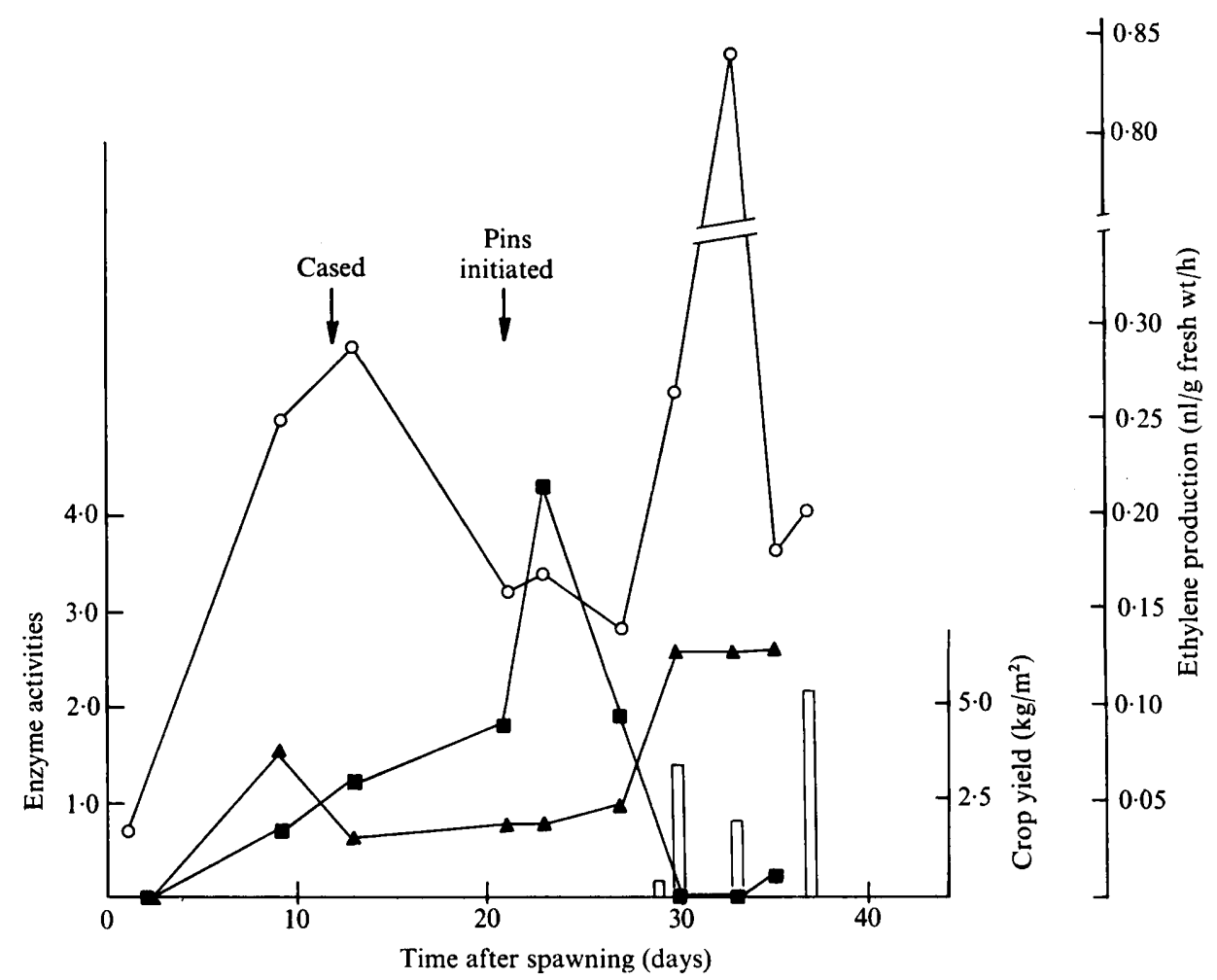

Fig. 4. Activities of laccase $(\boldsymbol{E})$ and cellulase $(\Delta)$ and the production of ethylene $(0)$ during the development of crop 156 in a commercial mushroom bed. Laccase activity is expressed as the increase in extinction (colorimeter units) per $\mathrm{mg}$ dry weight in $7 \mathrm{~min}$. Cellulase activity is expressed in arbitrary units based on the percentage reduction in viscosity per mg dry weight of sample. The histogram indicates the crop yield.

Preliminary data indicate that the fall in laccase and the rise in cellulase coincides with the onset of rapid elongation of the stipe. The levels of laccase and cellulase in extracts prepared from casing were uniformly low at all stages of crop development.

When flasks containing autoclaved compost were colonized and then cased with sterile casing soil so that no fruiting occurred, the switch from high laccase to high cellulase did not occur.

\section{DISCUSSION}

A number of volatile hydrocarbons not previously reported to be produced by $A$. bisporus have been identified as products both in commercial beds and in axenic laboratory cultures. In contrast to the other volatiles detected, the production of ethylene appeared to be related to the reproductive phase of the crop, as evidenced by the marked increase in evolution that occurred when fruiting bodies developed (Fig. 2). Further, no burst of ethylene occurred when sterile casing was used. However, once the fruit body reached a certain size (Fig. 4) the elevated pattern of ethylene production continued unaltered even if the fruit body was removed.

A similar situation was demonstrated for plugs of compost removed from the commercial beds at the time of fruit body expansion, for these plugs continued to produce high levels of ethylene at a linear rate for at least $6 \mathrm{~h}$ after removal from the bed. 
Clearly, at the expansion stage ethylene is produced by the mycelium-compost complex rather than by the fruit bodies themselves. The ability of the mycelium-compost complex to produce these bursts in ethylene suggests that some special physiological or metabolic change in the complex coincides with the development of the first fruit bodies. This view is supported by the finding that a switch in the levels of the enzymes cellulase and laccase occurred at this time, consistent with the successive utilization of lignin and cellulose found in mushroom beds by Gerrits (I968).

As shown in Figs. I to 4, there was an interval of about Io days between the initiation of fruit bodies and their maturity. During this time a small 'button mushroom' gradually developed. In the final $48 \mathrm{~h}$ of the ripening process there is a rapid elongation of the stipe and expansion of the cap, followed by veil-break and ripening of the first spores (Bonner, Kane \& Levey, I956). It was at this stage that the changes in ethylene, laccase and cellulase levels occurred (see Fig. 4).

Although we have established that in pure cultures on artificial media our strain of $A$. bisporus could produce cellulase and ethylene (unpublished results), the introduction of bacteria at the time of casing affords a possible additional source of both these compounds. This derives from the ethylene production by one of the many bacteria isolated irom our non-sterile casing (unpublished results) and the many reports of cellulase production by bacteria (Suzuke, Yamane \& Nisizawa, 1969).

However, it seems unlikely that such bacteria are directly responsible for the quantitative changes in enzyme activity and ethylene production during the change from the vegetative to the reproductive phase. Although, under normal conditions of growth of the mushroom crop, bacteria are necessary to initiate the reproductive phase (Eger, 1972), a number of experiments (Eger 1972; Long \& Jacobs, I974; Hayes, Randle \& Last, 1969) suggest that initiation is provoked by the observance of very special environmental conditions normally provided by the association with the bacteria. Clearly, if these quantitative changes in enzyme activity and ethylene production occur in special conditions in the absence of bacteria, then they must originate within the fungal mycelium.

It is widely recognized that quantitative changes in production of certain enzymes occur at particular times in the life cycles of some fungi. An increase in tyrosinase activity is symptomatic of the change from the vegetative to the reproductive phase both in pure cultures of fungi (Hirsch, 1954; Wilson, I968) and in the non-sterile casing soil of $A$. bisporus (Turner, 1974). We suggest that the enzyme switch to high cellulase activity in the compost which is reported in this paper, and which characterizes the first phase of fruit body expansion, is a similar phenomenon attributable to the fungal mycelium.

The bursts in ethylene production coincide with the expansion of every fruit body whilst the cellulase activity remains constant at a high level throughout the reproductive phase. Thus ethylene production may be the first parameter to be discovered which is associated with the successive 'breaks' of mushrooms in the commercial beds.

Investigations are continuing with the aim of elucidating the requirement for casing bacteria during differentiation in $A$. bisporus, and the significance of the ethylene production and enzyme changes during fruit body expansion.

We thank Dr P. M. E. Altham of the Statistical Laboratory, Cambridge University for her time and advice on statistical analyses of the data given in Table 2, and Mr D. Walters of the Agricultural Research Council Statistics Group, Department of Applied Biology, Cambridge for the statistical computations. We thank Mrs Hauser and the Directors of White Queen Ltd for their encouragement and permission to publish the work and for the 
provision of the Hauser Research Award to T.W. The unfailing help of Mr J. A. Peaker, who provided us with compost and allowed the sampling of trays during cropping in the White Queen Test Unit, is also gratefully acknowledged. R. Self acknowledges the assistance of $\mathrm{Mr} \mathrm{K}$. R. Parsley in performing the mass spectral analyses. We all thank Professor P. W. Brian for his encouragement and Mrs Ruth Foreman for preparing the diagrams.

\section{REFERENCES}

Abeles, F. B. (1973). Ethylene in Plant Biology. New York and London: Academic Press.

BonNeR, J. T., KANE, K. K. \& LeVEy, R. H. (1956). Studies on the mechanics of growth in the common mushroom, Agaricus campestris. Mycologia 48, I3-19.

Cornu, A. \& Massot, R. (1966). Compilation of Mass Spectral Data. London: Heyden.

EGER, G. (1972). Experiments and comments on the action of bacteria on sporophore initiation in Agaricus bisporus. Mushroom Science 8, 719-725.

GerRITs, J. P. G. (I968). Organic compost constituents and water utilized by the cultivated mushroom during spawn run and cropping. Mushroom Science 7, II I-126.

HAYes, W. A., RANDLE, P. E. \& LAST, F. T. (I969). The nature of the microbial stimulus affecting sporophore formation in Agaricus bisporus (Lange) Sing. Annals of Applied Biology 64, 177-187.

HIRSCH, H. M. (1954). Environmental factors influencing the differentiation of protoperithecia and their relation to tyrosinase and melanin formation in Neurospora crassa. Physiologia plantarum 7, 72-97.

Horowitz, N. H. \& FLING, M. (I953). Genetic determination of tyrosinase thermostability in Neurospora. Genetics 38, 360-374.

JACKSON, M. B. \& OsBORNE, D. J. (1972). Abscisic acid, auxin and ethylene in explant abscission. Journal of Experimental Botany 23, 849-62.

LAMBERT, E. B. (1933). Effect of excess carbon dioxide on growing mushrooms. Journal of Agricultural Research 47, 599-608.

LOCKARD, J. D. \& KNEEBone, O. R. (I962). Investigation of the metabolic gases produced by Agaricus bisporus (Lange) Sing. Mushroom Science 5, 281-299.

LoNG, P. E. \& JACOBS, L. (1974). Aseptic fruiting of the cultivated mushroom, Agaricus bisporus. Transactions of the British Mycological Society 63, 99-107.

MADER, E. O. (1943). Some factors inhibiting the fructification and production of the cultivated mushroom, Agaricus campestris. Phytopathology 33, I $134-1135$.

Richter, E. (1967). Über den Einfluss des Verschliessens von Champignon-Brut-Flaschen mit Polypropylenfolie auf den Stoffwechsel des wachsenden Mycels. Gartenbauwissenschaft 32, 33I-342.

SCHISLER, L. C. (1957). A physiological investigation of sporophore initiation in the cultivated mushroom Agaricus campestris. Ph.D. thesis, Pennsylvania State University, U.S.A.

SuzuKe, H., Yamane, K. \& Nisizawa, K. (1969). Intracellular and cell bound cellulase components of bacteria. In Cellulases and Their Applications, pp. 60-82. Edited by R. F. Gould. Advances in Chemistry Series, vol. 95. Washington, D.C.: American Chemical Society.

TSCHIERPE, H. J. \& SINDEN, J. W. (1964). Weitere Untersuchungen über die Bedeutung von Kohlendioxyd für die Fructification des Kulturchampignons, Agaricus campestris var. bisporus. Archiv für Mikrobiologie 49, 405-425.

TsChIERPE, H. J. \& Sinden, J. W. (1965). Über leicht flïchtige Produkte des aeroben und anaeroben Stoffwechsels des Culturchampignons, Agaricus campestis var. bisporus (L.) Lge. Archiv. für Mikrobiologie 52, 231-24I.

TURNER, E. M. (1974). Phenoloxidase activity in relation to substrate and development stage in the mushroom, Agaricus bisporus. Transactions of the British Mycological Society 63, 54I-547.

WILSON, D. M. (I968). Physiology of sexual reproduction in Hypomyces solani f. sp. cucurbitae. V. Effect of tyrosinase. Phytopathology 58, 1697-1699. 